\title{
PENGARUH PENGAWASAN INTERNAL, PEMAHAMAN SISTEM AKUNTANSI KEUANGAN, DAN KAPASITAS SUMBER DAYA MANUSIA TERHADAP KUALITAS INFORMASI LAPORAN KEUANGAN PEMERINTAH DAERAH PADA SKPD PEMERINTAH KOTA MANADO
}

\author{
Irene Fransisca Ponamon
}

(Email : ireneponamon@ymail.com)

\begin{abstract}
The research was conducted on the basis of the results of Local Government Finance Report that the financial statements of Manado City Government has not met the criteria as requirements quality financial statements. This is evidenced by the opinion received by the Manado City Government during 2008 to 2012 as, Qualified Opinion, Adverse Opinion, Disclaimer Opinion, Adverse Opinion, and Qualified Opinion. Adverse and Disclaimer Opinions received by the city of Manado may raise questions for society about possible irregularities have occurred many budgets.

This study aims to determine the influence of internal controls, an understanding of financial accounting systems, and human resources capacity to quality of government financial reporting information at SKPD in Manado city government. The results of the study were statistically conclude that internal control, understanding financial accounting, and human resource capacity jointly affect the quality of government financial reporting information at SKPD in Manado city, however partially, the human resource capacity has no effect to quality of government financial reporting information at SKPD in Manado City. Suggestions from this study is Manado City Government is expected to improve qualifications in the field of education, namely the employees who receive educational background in accounting.

Keywords: Quality of Government Financial Reporting Information, Internal Audit, Understanding of Financial Accounting System, Human Resources Capacity.
\end{abstract}

\section{PENDAHULUAN}

\subsection{Latar Belakang Masalah}

Masih banyaknya fenomena laporan keuangan pemerintah yang belum menyajikan data-data yang sesuai dengan peraturan dan masih banyak penyimpangan-penyimpangan yang berhasil ditemukan oleh Badan Pemeriksa Keuangan (BPK) dalam pelaksanaan audit laporan keuangan pemerintah membuat tuntutan masyarakat terhadap penyelenggaraan pemerintahan yang baik (good governance government) meningkat. Hal itu juga yang telah mendorong pemerintah pusat dan pemerintah daerah untuk menerapkan akuntabilitas publik. Harus disadari bahwa ada banyak pihak yang akan mengandalkan informasi dalam laporan keuangan yang dipublikasikan oleh pemerintah daerah sebagai dasar untuk pengambilan keputusan.

Laporan keuangan yang dihasilkan oleh pemerintah daerah akan digunakan oleh beberapa pihak yang berkepentingan sebagai dasar untuk pengambilan keputusan. Oleh karena itu, informasi yang terdapat di dalam Laporan Keuangan Pemerintah Daerah (LKPD) harus bermanfaat dan sesuai dengan kebutuhan para pemakai. Oleh karena itu, pemerintah daerah wajib memperhatikan informasi yang disajikan dalam laporan keuangan untuk keperluan perencanaan, pengendalian, dan pengambilan keputusan.

Pihak-pihak pengguna laporan keuangan pemerintah antara lain, masyarakat, para wakil rakyat, lembaga pengawas, lembaga pemeriksa, pihak yang memberi atau berperan dalam proses donasi, pers, investor, kreditor serta pihak-pihak lain yang berkepentingan (Mahmudi, $2010: 2$ ) 
Dalam kenyataannya, fenomena yang terjadi saat ini masih banyak laporan keuangan yang disusun tidak berkualitas. Hal ini dibuktikan dengan masih banyak Laporan Keuangan Pemerintah Daerah (LKPD) yang tidak memperoleh opini BPK wajar tanpa pengecualian (WTP). Opini yang diperoleh oleh Pemerintah Kota Manado dari tahun 2008 - 2012 yaitu wajar dengan pengecualian (WDP), tidak wajar (TW), tidak memberikan pendapat (TMP), tidak wajar (TW), dan wajar dengan pengecualian (WDP). Opini tidak wajar dan tidak memberikan pendapat yang diterima oleh kota Manado tersebut dapat menimbulkan pertanyaan dari kalangan masyarakat mengenai kemungkinan telah terjadi banyak penyimpangan anggaran.

Secara umum, beberapa faktor yang menyebabkan laporan keuangan tersebut belum memperoleh opini WTP adalah karena lemahnya pengawasan internal, penyajian yang belum sepenuhnya sesuai Standar Akuntansi Pemerintah (SAP), ketidakpatuhan terhadap peraturan perundang-undangan, dan kurang memadainya kapasitas SDM pengelola keuangan.

Dari latar belakang diatas maka judul penelitian yang diteliti adalah "Pengaruh pengawasan internal, pemahaman sistem akuntansi keuangan, dan kapasitas sumber daya manusia terhadap kualitas informasi laporan keuangan pemerintah daerah pada SKPD Pemerintah Kota Manado".

\subsection{Rumusan Masalah}

Berdasarkan uraian pada latar belakang penelitian, maka masalah yang akan diidentifikasi adalah sebagai berikut.

1. Apakah pengawasan internal berpengaruh terhadap kualitas informasi laporan keuangan pemerintah daerah pada Pemerintah Kota Manado?

2. Apakah pemahaman sistem akuntansi keuangan berpengaruh terhadap kualitas informasi laporan keuangan pemerintah daerah pada Pemerintah Kota Manado?

3. Apakah kapasitas sumber daya manusia berpengaruh terhadap kualitas informasi laporan keuangan pemerintah daerah pada Pemerintah Kota Manado?

\subsection{Tujuan Penelitian}

Sesuai dengan permasalahan dan pertanyaan penelitian, maka tujuan yang ingin dicapai penulis dalam penelitian ini adalah untuk mengetahui, menganalisis dan memperoleh bukti empiris sebagai berikut.

1. Bahwa pengawasan internal berpengaruh terhadap kualitas informasi laporan keuangan pemerintah daerah pada Pemerintah Kota Manado.

2. Bahwa pemahaman sistem akuntansi berpengaruh terhadap kualitas informasi laporan keuangan pemerintah daerah pada Pemerintah Kota Manado.

3. Bahwa kapasitas sumber daya manusia berpengaruh terhadap kualitas informasi laporan keuangan pemerintah daerah pada Pemerintah Kota Manado.

\subsection{Manfaat Penelitian} berikut.

Selain itu, melalui hasil penelitian ini diharapkan dapat memberikan manfaat sebagai

1. Kontribusi empiris, untuk menguji pengaruh pengawasan internal, pemahaman sistem akuntansi keuangan, dan kapasitas sumber daya manusia terhadap kualitas informasi laporan keuangan pemerintah kota Manado.

2. Memberikan masukan bagi pemerintah kota Manado yang berkaitan dengan implementasi pengawasan internal, pemahaman sistem akuntansi keuangan dan kapasitas sumber daya manusia.

3. Penelitian ini diharapkan memperkaya hasil penelitian dan sebagai bahan referensi peneliti lain yang akan meneliti hal yang sama. 


\section{TINJAUAN PUSTAKA}

\subsection{Pengawasan Internal}

Pengawasan adalah suatu upaya yang sistematik untuk menetapkan kinerja standar pada perencanaan untuk merancang sistem umpan balik informasi, untuk membandingkan kinerja aktual dengan standar yang telah ditentukan, untuk menetapkan apakah telah terjadi suatu penyimpangan tersebut, serta untuk mengambil tindakan perbaikan yang diperlukan untuk menjamin bahwa semua sumber daya perusahaan atau pemerintahan telah digunakan seefektif dan seefisien mungkin guna mencapai tujuan perusahaan atau pemerintahan (Jurnal Kementerian Dalam Negeri, 2010).

\subsection{Pemahaman Sistem Akuntansi Keuangan}

Sistem Akuntansi Pemerintah Daerah adalah sistem terpadu yang menggabungkan prosedur manual dengan proses elektronis dalam pengambilan data, pembukuan dan pelaporan semua transaksi keuangan, aset, utang dan ekuitas seluruh entitas Pemerintah Daerah. Dalam implementasi pengelola keuangan daerah diharapkan para pengelola perlu memiliki pemahaman memadai tentang sistem akuntansi keuangan daerah agar dapat menyajikan laporan keuangan yang handal. Sistem informasi akuntansi dalam sistem perencanaan dan pengendalian sektor publik mempunyai arti dan peran penting terkait pada fungsinya dalam pengukuran dan pengendalian.

\subsection{Kapasitas Sumber Daya Manusia}

Kapasitas sumber daya manusia adalah kemampuan seseorang atau individu, suatu organisasi/kelembagaan, atau suatu sistem untuk melaksanakan fungsi-fungsi atau kewenangannya untuk mencapai tujuannya secara efektif dan efisien. Kemampuan sumber daya manusia menurut Robbins (2006 : 52) diartikan sebagai kapasitas individu untuk mengerjakan berbagai tugas dalam pekerjaan tertentu. Kemampuan keseluruhan seseorang pada hakikatnya terdiri dari dua faktor, yaitu kemampuan intelektual dan kemampuan fisik. Dalam pekerjaan terkait kegiatan administrasi pada suatu organisasi, kemampuan intelektual tentu lebih dominan. Kemampuan intelektual seseorang dalam menyelesaikan pekerjaan tertentu bersumber dari latar belakang pendidikan dan pengalaman yang dimilikinya.

\subsection{Laporan Keuangan}

Mahmudi (2010 : 2) mengemukakan bahwa terkait dengan tugasnya untuk menegakkan akuntabilitas keuangan, khususnya di daerah, pemerintah daerah bertanggungjawab untuk mempublikasikan laporan keuangan kepada pemangku kepentingannya. Terdapat dua alasan mengapa pemerintah daerah perlu mempublikasikan laporan keuangan tersebut, yaitu sebagai berikut.

1. Dari sisi internal, laporan keuangan merupakan alat pengendali dan evaluasi kinerja bagi pemerintah daerah secara keseluruhan maupun unit-unit kerja didalamnya (SKPD).

2. Dari sisi eksternal, laporan keuangan pemerintah daerah merupakan bentuk pertanggungjawaban eksternal, yaitu pertanggungjawaban kepala daerah kepada masyarakat, investor, kreditor, lembaga donor, pers, serta pihak-pihak lain yang berkepentingan.

\subsection{Kualitas Informasi Laporan Keuangan}

Peraturan Pemerintah No. 24 Tahun 2005 menjelaskan karakteristik kualitatif laporan keuangan adalah ukuran-ukuran normatif yang perlu diwujudkan dalam informasi akuntansi sehingga dapat memenuhi tujuannya. Karakteristik kualitatif merupakan prasyarat normatif 
yang diperlukan agar laporan keuangan pemerintah dapat memenuhi kualitas yang dikehendaki. Karakteristik kualitatif tersebut antara lain sebagai berikut.

1. Relevan

2. Andal

3. Dapat dibandingkan

4. Dapat dipahami

\subsection{Penelitian Terdahulu}

Susilo Prapto (2008), melakukan penelitian yang berjudul pengaruh pemanfaatan teknologi informasi, dan pengendalian intern akuntansi terhadap pelaporan keuangan pemerintah daerah. Metode pengumpulan data menggunakan kuesioner, sedangkan teknik analisis data yang digunakan adalah teknik uji instrumen meliputi uji validitas dan uji reliabilitas; uji asumsi klasik meliputi uji multikolinieritas, uji heteroskedastisitas, uji autokorelasi dan uji normalitas; pengujian hipotesis dengan regresi.Hasil penelitian menunjukkan bahwa pemanfaatan teknologi informasi dan pengendalian intern akuntansi berpengaruh signifikan terhadap pelaporan keuangan pemerintah daerah. Winidyaningrum dan Rahmawati (2010) meneliti pengaruh sumber daya manusia dan informasi teknologi pemanfaatan kehandalan dan ketepatan waktu pelaporan keuangan pemerintah daerah dengan variabel intervening pengendalian internal akuntansi. Hasil penelitiannya menyatakan Sumber daya manusia berpengaruh positif signifikan terhadap keterandalan pelaporan keuangan pemerintah daerah, tetapi tidak signifikan terhadap ketepatwaktuan.Pemanfaatan TI berpengaruh positif signifikan terhadap keterandalan pelaporan dan ketepatwaktuan. Zuliarti (2012), meneliti pengaruh kapasitas sumber daya manusia,pemanfaatan teknologi informasi, dan pengendalian intern akuntansi terhadap nilai informasi pelaporan keuangan pemerintah daerah: studi pada pemerintah kabupaten kudus. Hasil penelitian menyatakan pertama, pemanfaatan teknologi informasi dan pengendalian intern akuntansi mempunyai pengaruh positif dan signifikan terhadap keterandaalan pelaporan keuangan pemerintah sedangkan kapasitas SDM tidak berpengaruh. Kedua, baik kapasitas SDM dan pemanfaatan teknologi informasi mempunyai pengaruh positif dan signifikan terhadap keterandaalan pelaporan keuangan pemerintah daerah.

\section{KERANGKA KONSEPTUAL}

\subsection{Kerangka Konseptual Penelitian}

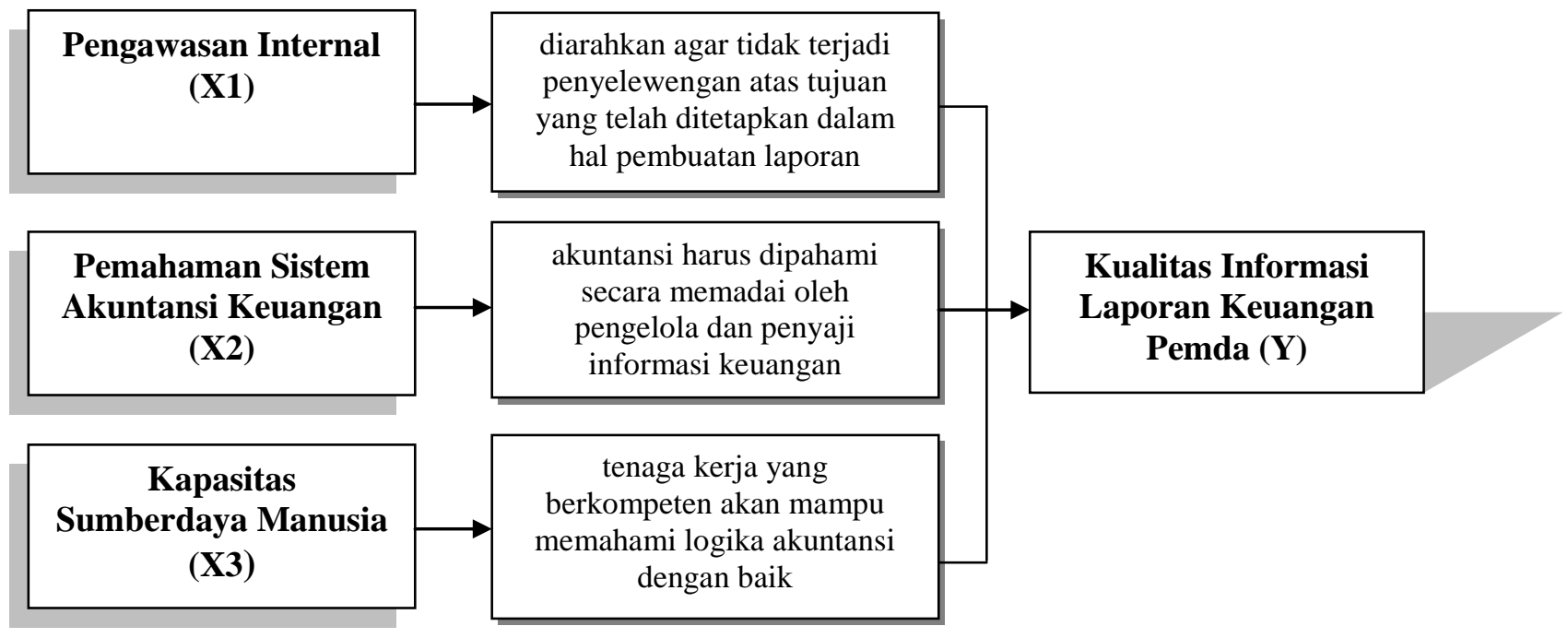

Gambar 3.1 Kerangka Konseptual Penelitian 


\subsection{Hipotesis}

$\mathrm{H}_{1}$ : Pengawasan internal berpengaruh terhadap kualitas informasi laporan keuangan pemerintah daerah.

$\mathrm{H}_{2}$ : Pemahaman sistem akuntansi berpengaruh terhadap kualitas informasi laporan keuangan pemerintah daerah.

$\mathrm{H}_{3}$ : Kapasitas sumber daya manusia berpengaruh terhadap kualitas informasi laporan keuangan pemerintah daerah.

\section{METODE PENELITIAN}

\subsection{Jenis dan Sumber Data}

Jenis penelitian ini adalah penelitian kausal, Umar (2008 : 10) menyebutkan disain kausal berguna untuk menganalisis bagaimana suatu variabel mempengaruhi variabel lain, dan juga berguna pada penelitian yang bersifat eksperimen dimana variabel independennya diperlakukan secara terkendali oleh peneliti untuk melihat dampaknya pada variabel dependennya secara langsung. Data yang digunakan dalam penelitian ini adalah data primer yaitu dengan menggunakan kuesioner sebagai alat analisis.

\subsection{Populasi dan Sampel}

Populasi dalam penelitian ini adalah SKPD yang berada di Pemerintah Kota Manado antara lain Sekretariat Daerah, Sekretariat DPRD, Dinas, Badan, Kantor, dan Kecamatan dengan jumlah populasi sebanyak 46 SKPD. Penyampelan atas responden pada penelitian ini dilakukan dengan teknik purposive sampling. Purposive sampling digunakan karena informasi yang akan diambil berasal dari sumber yang sengaja dipilih berdasarkan kriteria yang telah ditetapkan. (Sekaran, 2003). Kriteria yang ditetapkan peneliti antara lain sebagai berikut.

1. Pegawai Negeri Sipil di SKPD Pemerintah Kota Manado

2. Pegawai yang melaksanakan fungsi akuntansi/tata usaha keuangan pada SKPD di Pemerintah Kota Manado.

3. Pegawai yang bekerja sebagai Kepala Bagian dan staf bagian Akuntansi/Keuangan SKPD pada Pemerintah Kota Manado.

Dari populasi sebanyak 46 tersebut akan diambil sejumlah sampel dengan menggunakan rumus sebagai berikut.

dimana:

$$
\mathrm{n}=\frac{\mathrm{N}}{1+\mathrm{Ne}^{2}}
$$

$\mathrm{n}=$ ukuran sampel

$\mathrm{N}=$ ukuran populasi

$\mathrm{e}=$ ukuran kelonggaran karena ketidakpastian yang masih ditolerir 5\%-10\%

Menurut Slovin dikutip oleh Husein Umar (2008 : 108), besarnya sampel yang diambil adalah sebagai berikut.

$$
\begin{aligned}
& \mathrm{n}=\frac{46}{1+46(0.1)^{2}} \\
& \mathrm{n}=31,50 \\
& \mathrm{n}=32 \text { SKPD }
\end{aligned}
$$




\subsection{Cara Pengolahan dan Analisis Data}

Cara pengolahan dan analisis data dalam penelitian ini sebagai berikut.

1. Uji Validitas dan Reliabilitas

2. Uji Asumsi Klasik

3. Analisis Regresi Linier Berganda: $Y=\alpha+\beta_{1} X_{1}+\beta_{2} X_{2}+\beta_{3} X_{3}+e$

4. Uji F dan Uji t

5. Koefisien Korelasi dan Koefisien Determinasi

5. ANALISIS DAN PEMBAHASAN HASIL PENELITIAN

5.1 Uji Validitas dan Reliabilitas

Tabel 5.1 Uji Validitas dan Reliabilitas

\begin{tabular}{|c|c|c|c|c|}
\hline \multicolumn{5}{|c|}{ Reliability Statistics } \\
\hline \multicolumn{2}{|c|}{$\begin{array}{l}\text { Cronbach's Alpha } \\
.803\end{array}$} & \multicolumn{3}{|c|}{$\begin{array}{l}\mathrm{N} \text { of Items } \\
8\end{array}$} \\
\hline \multicolumn{5}{|c|}{ Item-Total Statistics } \\
\hline & $\begin{array}{l}\text { Scale Mean if } \\
\text { Item Deleted }\end{array}$ & $\begin{array}{l}\text { Scale Variance } \\
\text { if Item Deleted }\end{array}$ & $\begin{array}{l}\text { Corrected } \\
\text { Item-Total } \\
\text { Correlation }\end{array}$ & $\begin{array}{l}\text { Cronbach's } \\
\text { Alpha if Item } \\
\text { Deleted }\end{array}$ \\
\hline $\mathrm{P} 1 \mathrm{Y}$ & 44.72 & 33.218 & .817 & .777 \\
\hline $\mathrm{P} 2 \mathrm{Y}$ & 44.90 & 32.652 & .910 & .770 \\
\hline P3Y & 44.82 & 32.939 & .847 & .774 \\
\hline P4Y & 44.85 & 32.469 & .935 & .768 \\
\hline P5Y & 44.99 & 32.690 & .755 & .774 \\
\hline P6Y & 44.96 & 33.055 & .855 & .775 \\
\hline P7Y & 44.93 & 33.305 & .796 & .778 \\
\hline $\begin{array}{l}\text { Kualitas Informasi } \\
\text { Laporan Keuangan }\end{array}$ & 24.17 & 9.521 & 1.000 & .944 \\
\hline
\end{tabular}

(Sumber: data hasil olahan SPSS)

Hasil uji validitas dan reliabilitas untuk pertanyaan 1-7 untuk variabel $\mathrm{X}_{1} \mathrm{X}_{2} \mathrm{X}_{3}$ dan $\mathrm{Y}$, mempunyai nilai korelasi di atas 0,30 dan cronbach alpha 0,803. Semua dinyatakan reliabel dan valid.

\subsection{Uji Asumsi Klasik}

1. Uji Normalitas

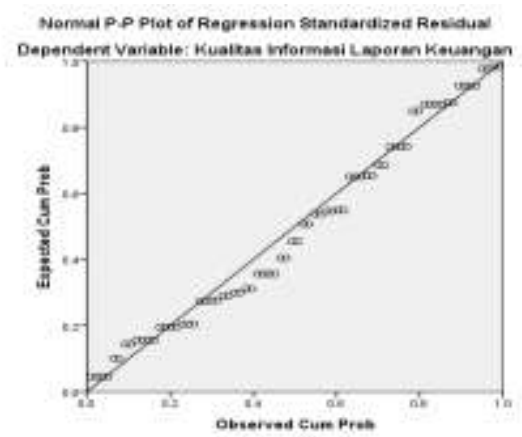

Sumber: Hasil Olah Data (2013)

Gambar 5.1 Uji Normalitas 
Berdasarkan Gambar 5.1 terlihat bahwa grafik Normal P-P Plot of regression standardized residual menggambarkan penyebaran data tersebar di sekitar garis diagonal dan penyebarannya mengikuti arah garis diagonal grafik tersebut, maka model regresi yang digunakan dalam penelitian ini telah memenuhi asumsi normalitas.

\section{Uji Heteroskedastisitas}
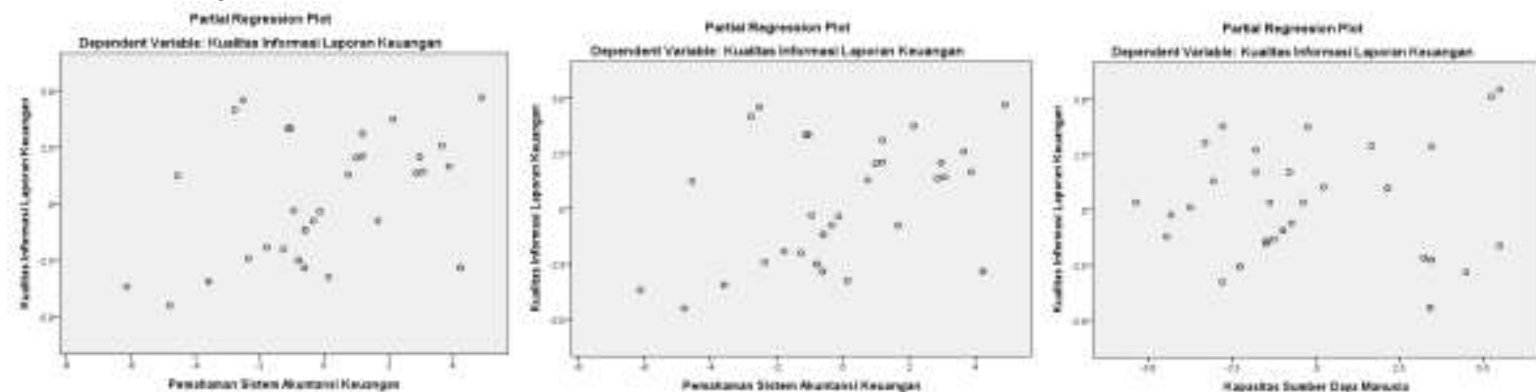

Sumber: Hasil Olah Data (2013)

Gambar 5.2 Uji Heteroskedastisitas

Pada gambar 5.2 terlihat bahwa titik-titik grafik plot yang diperoleh, tidak membentuk suatu pola yang jelas, serta titik-titik menyebar diatas dan dibawah angka 0 (nol) pada sumbu Y, maka hal ini membuktikan tidak terjadi Heteroskedastisitas.

\section{Uji Multikolinearitas}

Tabel 5.2 Uji Multikolinearitas

\begin{tabular}{|c|l|r|r|}
\hline \multicolumn{2}{|c|}{ Model } & \multicolumn{2}{c|}{ Collinearity Statistics } \\
\cline { 2 - 4 } \multicolumn{2}{|c|}{} & Tolerance & \multicolumn{1}{c|}{ VIF } \\
\cline { 2 - 4 } 1 & Constant) & .819 & 1.221 \\
\cline { 2 - 4 } & Pengawasan Internal & .826 & 1.211 \\
\cline { 2 - 4 } & Pemahaman Sistem Akuntansi Keuangan & .841 & 1.189 \\
\cline { 2 - 4 } & Kapasitas Sumber Daya Manusia & &
\end{tabular}

Sumber: Hasil Olah Data SPSS (2013)

Berdasarkan hasil coefficients yang terdapat pada tabel 5.2 dapat dilihat pada output coefficients model, dikatakan tidak terjadi gejala multikolinearitas jika VIF < 10dan nilai tolerance $>0,10$.

\subsection{Analisis Regresi Linier Berganda}

$$
Y=8,745+0,324 X_{1}+0,366 X_{2}-0,015 X_{3}+\varepsilon
$$

Tabel 5.3 Koefisien Regresi

\begin{tabular}{llrr}
\hline & \multicolumn{1}{c}{ Model } & \multicolumn{2}{c}{ Unstandardized Coefficients } \\
\cline { 3 - 4 } & (Constant) & B & Std. Error \\
\hline \multirow{2}{*}{1} & Pengawasan Internal & 8.745 & 2.992 \\
& Pemahaman Sistem Akuntansi Keuangan & .324 & .103 \\
& Kapasitas Sumber Daya Manusia & .366 & .113 \\
\hline
\end{tabular}

Sumber: Hasil Olah Data (2013)

Nilai dari variabel Pengawasan Internal atau $b_{1}$ adalah positif $(0,324)$. Nilai koefisien regresi $b_{1}$ ini menunjukkan bahwa variabel pengawasan internal mempunyai pengaruh 
hubungan positif dan searah terhadap variabel kualitas informasi laporan keuangan secara statistik. Hal ini berarti bahwa apabila pengawasan internal meningkat sebesar 1 satuan score dari kondisi sebelumnya, maka kualitas informasi laporan keuangan pemerintah daerah pada SKPD pemerintah kota Manado juga ikut meningkat sebesar 0,324 satuan score. Nilai variabel Pemahaman Sistem Akuntansi Keuangan atau $b_{2}$ adalah positif $(0,366)$. Nilai koefisien regresi $b_{2}$ ini menunjukkan bahwa variabel pemahaman sistem akuntansi keuangan mempunyai pengaruh hubungan positif dan searah terhadap variabel kualitas informasi laporan keuangan secara statistik. Hal ini berarti bahwa apabila pemahaman sistem akuntansi keuangan meningkat sebesar 1 satuan score, maka kualitas informasi laporan keuangan pemerintah daerah pada SKPD pemerintah kota Manado juga akan meningkat sebesar 0,366 satuan score. Nilai variabel Kapasitas Sumber Daya Manusia atau $b_{3}$ adalah negatif $(-0,015)$. Nilai koefisien regresi $b_{3}$ ini menunjukkan bahwa variabel kapasitas sumber daya manusia mempunyai hubungan negatif terhadap kualitas informasi laporan keuangan pemerintah daerah pada SKPD Pemerintah Kota Manado.

\section{$5.4 \quad$ Uji Hipotesis (Uji F)}

Tabel 5.4 ANOVA ${ }^{\mathrm{a}}$

\begin{tabular}{rlrrrrr}
\hline Model & & Sum of Squares & df & Mean Square & F & Sig. \\
\hline \multirow{3}{*}{1} & Regression & 220.599 & 3 & 73.533 & 10.980 & $.000^{\mathrm{b}}$ \\
& Residual & 455.401 & 68 & 6.697 & & \\
& Total & 676.000 & 71 & & & \\
\hline
\end{tabular}

Sumber: Hasil Olah Data (2013)

Berdasarkan Tabel 5.4 nilai $\mathrm{F}_{\text {hitung }}=10,980$. Angka ini lebih besar dari $\mathrm{F}_{\text {tabel }}=2,74$ pada tingkat $\alpha=0,05$. Dengan demikian maka dapat disimpulkan bahwa $\mathrm{H}_{\mathrm{o}}$ ditolak dan $\mathrm{H}_{\mathrm{a}}$ diterima. Hal ini berarti, Pengawasan Internal $\left(\mathrm{X}_{1}\right)$, Pemahaman Sistem Akuntansi Keuangan $\left(\mathrm{X}_{2}\right)$, dan Kapasitas Sumber Daya Manusia $\left(\mathrm{X}_{3}\right)$ secara bersama-sama berpengaruh terhadap Kualitas Informasi Laporan Keuangan (Y).

\section{$5.5 \quad$ Uji Hipotesis (Uji t)}

Tabel 5.5 Uji t

\begin{tabular}{|c|c|c|c|c|c|c|}
\hline \multirow{3}{*}{\multicolumn{2}{|c|}{ Model }} & \multirow{3}{*}{$\begin{array}{c}\text { Standardized } \\
\text { Coefficients }\end{array}$} & \multirow[t]{3}{*}{$\mathrm{t}$} & \multirow[t]{3}{*}{ Sig. } & \multicolumn{2}{|c|}{$\begin{array}{l}\text { 95,0\% Confidence } \\
\text { Interval for B }\end{array}$} \\
\hline & & & & & Lower & Upper \\
\hline & & & & & Bound & Bound \\
\hline \multirow{4}{*}{1} & (Constant) & & 2.923 & .005 & 2.775 & 14.716 \\
\hline & Pengawasan Internal & .347 & 3.159 & .002 & .119 & .529 \\
\hline & $\begin{array}{l}\text { Pemahaman Sistem Akuntansi } \\
\text { Keuangan }\end{array}$ & .353 & 3.227 & .002 & .139 & .592 \\
\hline & $\begin{array}{l}\text { Kapasitas Sumber Daya } \\
\text { Manusia }\end{array}$ & -.016 & -.149 & .882 & -.213 & .184 \\
\hline
\end{tabular}

Sumber: Hasil Olah Data (2013)

Pada Tabel 5.5 diketahui hasil uji t untuk variabel Pengawasan Internal $\left(\mathrm{X}_{1}\right)$. Nilai $t_{\text {hitung variabel }} \mathrm{X}_{1}$ adalah 3,159. Dengan tingkat kepercayaan 5\% pada derajat kebebasan $(\mathrm{N}-2)$ $=72-2=70$, dapat diketahui nilai $t_{\text {tabel }}$ sebesar 2,000. Berdasarkan hasil output regresi diatas, diperoleh nilai $t_{\text {hitung }}>t_{\text {tabel }}$, dengan demikian $\mathrm{H}_{1}$ diterima atau dengan kata lain 
variabel Pengawasan Internal $\left(\mathrm{X}_{1}\right)$ berpengaruh terhadap Kualitas Informasi Laporan Keuangan pada SKPD Pemerintah Kota Manado.

Untuk variabel Pemahaman Sistem Akuntansi Keuangan $\left(\mathrm{X}_{2}\right)$. Nilai $t_{\text {hitung variabel }} \mathrm{X}_{2}$ adalah 3,227. Dengan tingkat kepercayaan 5\% pada derajat kebebasan $(\mathrm{N}-2)=72-2=70$, dapat diketahui nilai $t_{\text {tabel }}$ sebesar 2,000. Berdasarkan hasil output regresi diatas, diperoleh nilai $t_{\text {hitung }}>t_{\text {tabel, }}$, dengan demikian $\mathrm{H}_{2}$ diterima, atau dengan kata lain variabel Pemahaman Akuntansi Keuangan $\left(\mathrm{X}_{2}\right)$ berpengaruh terhadap Kualitas Informasi Laporan Keuangan pada SKPD Pemerintah Kota Manado. Untuk variabel Kapasitas Sumber Daya Manusia $\left(\mathrm{X}_{3}\right)$. Nilai $t_{\text {hitung }}$ variabel $\mathrm{X}_{3}$ adalah $-0,149$. Dengan tingkat kepercayaan 5\% pada derajat kebebasan $(\mathrm{N}$ $2)=72-2=70$, dapat diketahui nilai $t_{\text {tabel }}$ sebesar 2,000. Berdasarkan hasil output regresi diatas, diperoleh nilai $\mathrm{t}_{\text {hitung }}<\mathrm{t}_{\text {tabel, }}$, dengan demikian $\mathrm{H}_{3}$ ditolak, atau dengan kata lain variabel Kapasitas Sumber Daya Manusia $\left(\mathrm{X}_{3}\right)$ tidak berpengaruh terhadap Kualitas Informasi Laporan Keuangan pada SKPD Pemerintah Kota Manado.

\subsection{Koefisien Korelasi (r)}

Tabel 5.6 Koefisien Korelasi

\begin{tabular}{llr}
\hline & & $\begin{array}{r}\text { Kualitas Informasi } \\
\text { Laporan Keuangan }\end{array}$ \\
\hline \multirow{3}{*}{ Pearson Correlation } & 1.000 \\
& Kualitas Informasi Laporan Keuangan & .468 \\
& Pengawasan Internal & .472 \\
& Pemahaman Sistem Akuntansi Keuangan & .214 \\
Sig. (1-tailed) & Kapasitas Sumber Daya Manusia &. \\
& Kualitas Informasi Laporan Keuangan & .000 \\
& Pengawasan Internal & .000 \\
N & Kemahaman Sistem Akuntansi Keuangan & .036 \\
& Kualitas Informasi Laporan Keuangan & 72 \\
& Pengawasan Internal & 72 \\
& Pemahaman Sistem Akuntansi Keuangan & 72 \\
& Kapasitas Sumber Daya Manusia & 72 \\
\hline
\end{tabular}

Sumber: Hasil Olah Data (2013)

Berdasarkan hasil olah data, diketahui bahwa variabel Pengawasan Internal $\left(\mathrm{X}_{1}\right)$ mempunyai korelasi yang bersifat cukup dan positif dengan variabel Kualitas Informasi Laporan Keuangan (Y), hal ini ditunjukkan dengan nilai koefisien korelasi sebesar 0,468. Korelasi yang bersifat cukup dan positif juga terjadi pada variabel Pemahaman Sistem Akuntansi Keuangan $\left(\mathrm{X}_{2}\right)$ dengan variabel Kualitas Informasi Laporan Keuangan (Y), dengan nilai koefisien korelasi sebesar 0,472. Sedangkan untuk variabel Kapasitas Sumber Daya Manusia $\left(\mathrm{X}_{3}\right)$ mempunyai korelasi yang bersifat sangat lemah dan positif dengan variabel Kualitas Informasi Laporan Keuangan (Y), dengan nilai koefisien sebesar 0,214.

\section{$5.7 \quad$ Koefisien Determinasi $\left(\mathbf{R}^{2}\right)$}

Tabel 5.7 Koefisien Determinasi

\begin{tabular}{|c|c|c|c|c|}
\hline \multicolumn{5}{|c|}{ Model Summary $^{b}$} \\
\hline Model & $\mathrm{R}$ & R Square & Adjusted R Square & Std. Error of the Estimate \\
\hline 1 & $.571^{\mathrm{a}}$ & .326 & .297 & 2.588 \\
\hline
\end{tabular}

Sumber: Hasil Olah Data (2013) 
Berdasarkan tabel hasil output SPSS model summary dapat diketahui bahwa nilai koefisien determinasi atau $\mathrm{R}^{2}$ adalah sebesar 0,297 atau 29,7\%. Angka tersebut berarti sebesar 29,7\% kualitas informasi laporan keuangan pemerintah pada SKPD Pemerintah Kota Manado dapat dijelaskan oleh variabel Pengawasan Internal, Pemahaman Sistem Akuntansi Keuangan, dan Kapasitas Sumber Daya Manusia. Sedangkan sisanya $(100 \%-29,7 \%=$ 70,3\%) disebabkan oleh faktor-faktor lain diluar pengujian ini.

\subsection{Pembahasan}

Tujuan utama pengawasan bukan untuk mencari kesalahan, melainkan mengarahkan pelaksanaan aktivitas agar rencana yang telah ditetapkan dapat terlaksana secara optimal. Pengawasan atas penyelenggaraan Pemerintah Daerah diharapkan untuk menjamin agar pelaksanaan kegiatan pemerintahan berjalan sesuai dengan rencana dan sesuai dengan peraturan perundang-undangan yang berlaku. Dalam penelitian ini, diketahui bahwa secara parsial variabel Pengawasan Internal (X1), memiliki pengaruh terhadap Kualitas Informasi Laporan Keuangan (Y). Hal ini berarti bahwa kegiatan pengawasan internal pada SKPD Pemerintah Kota Manado telah menjamin bahwa semua pencatatan akuntansi dan keuangan pemerintah telah memberikan keyakinan memadai dan sesuai dengan prosedur dan peraturan yang berlaku, sehingga tujuan untuk membuat laporan keuangan yang berkualitas dapat tercapai. Hasil penelitian ini didukung oleh penelitian yang dilakukan oleh Novi Andiani (2012) yang menyimpulkan bahwa implementasi pengawasan berpengaruh terhadap pengelolaan keuangan daerah, dan penelitian yang dilakukan oleh Safrida (2010) yaitu audit internal berpengaruh terhadap kualitas informasi laporan keuangan pemerintah kota Banda Aceh.

Orang yang memiliki pemahaman akuntansi adalah orang yang pandai dan mengerti benar tentang akuntansi. Seseorang dikatakan paham terhadap akuntansi apabila orang tersebut mengerti dan pandai bagaimana proses akuntansi itu dilakukan sampai menjadi suatu laporan keuangan dengan berpedoman pada prinsip dan standar penyusunan laporan keuangan yang ditetapkan dalam peraturan perundang-undangan. Dalam penelitian ini, diketahui bahwa secara parsial Pemahaman Akuntansi Keuangan $\left(\mathrm{X}_{2}\right)$ berpengaruh terhadap Kualitas Informasi Laporan Keuangan (Y). Hal ini berarti bahwa pegawai bagian akuntansi/keuangan pada SKPD Pemerintah Kota Manado telah memahami proses akuntansi sampai menjadi laporan keuangan sehingga tujuan untuk membuat laporan keuangan yang berkualitas dapat tercapai. Hasil penelitian ini, didukung oleh penelitian yang dilakukan oleh Safrida (2010) yaitu pemahaman akuntansi berpengaruh terhadap kualitas laporan keuangan pemerintah kota Banda Aceh.

Secara parsial, berbeda dengan variabel pengawasan internal dan pemahaman sistem akuntansi keuangan yang memiliki pengaruh terhadap kualitas informasi laporan keuangan, untuk variabel Kapasitas Sumber Daya Manusia $\left(\mathrm{X}_{3}\right)$ memiliki pengaruh negatif terhadap Kualitas Informasi Laporan Keuangan (Y). Hal ini disebabkan karena kondisi kapasitas sumber daya manusia di bagian akuntansi/keuangan yang belum mendukung karena masih sedikit pegawai subbagian akuntansi/keuangan yang memiliki latar belakang pendidikan akuntansi dan hal ini terlihat dari data demografi responden. Hasil penelitian ini sejalan dengan penelitian yang dilakukan oleh Zuliarti (2012) yang menghasilkan kapasitas sumberdaya manusia tidak berpengaruh terhadap kualitas pelaporan keuangan. Hal ini disebabkan karena kondisi kapasitas sumberdaya manusia yang belum mendukung baik dari segi kualitas maupun kuantitas. Dari sisi kualifikasi, sebagian besar pegawai bagian akuntansi/keuangan tidak memiliki latar belakang pendidikan akuntansi. Uraian tugas dan fungsi bagian akuntansi/keuangan yang ada, masih belum terspesifikasi dengan jelas. Dari sisi kuantitas, masih sedikit jumlah akuntan atau pegawai yang berpendidikan tinggi akuntansi, sementara peraturan perundang-undangan telah mewajibkan setiap satuan kerja 
untuk menyelenggarakan akuntansi dan menyusun laporan keuangan. Oleh sebab itu, kelemahan yang ada harus diimibangi dengan mengikutsertakan pegawai dalam pelatihanpelatihan yang berhubungan dengan akuntansi dan pengelolaan keuangan daerah seperti pelatihan perpajakan, pelatihan bendahara, pelatihan SIMDA keuangan, pelatihan penatausahaan keuangan, dan sebagainya.

Hasil pengujian statistik uji bersama (Uji F) menyangkut pengawasan internal, pemahaman sistem akuntansi keuangan, dan kapasitas sumber daya manusia terhadap kualitas informasi laporan keuangan pemerintah pada SKPD Pemerintah Kota Manado diperoleh angka $F_{\text {hitung }}=10,980>F_{\text {tabel }}=2,74$. Hal ini berarti bahwa secara bersama-sama, pengawasan internal, pemahaman sistem akuntansi keuangan, dan kapasitas sumber daya manusia berpengaruh terhadap kualitas informasi laporan keuangan pemerintah pada SKPD Pemerintah Kota Manado.

Hasil olah data untuk R Square sebesar 0,297 atau 29,7\%. Angka tersebut berarti sebesar 29,7\% kualitas informasi laporan keuangan pemerintah pada SKPD Pemerintah Kota Manado dapat dijelaskan oleh variabel Pengawasan Internal, Pemahaman Sistem Akuntansi Keuangan, dan Kapasitas Sumber Daya Manusia. Sedangkan sisanya $(100 \%$ - 29,7\% = $70,3 \%$ ) disebabkan oleh faktor-faktor lain diluar pengujian ini. Faktor-faktor lain tersebut bisa disebabkan karena misalnya dari segi sarana dan prasarana teknologi, hal ini beralasan karena teknologi yang kurang memadai akan berpengaruh terhadap kualitas informasi laporan keuangan.

\section{PENUTUP \\ 6.1 Simpulan}

Dari hasil penelitian dan pembahasan maka dapat disimpulkan beberapa kesimpulan sebagai berikut.

1. Diketahui bahwa secara parsial variabel Pengawasan Internal (X1), memiliki pengaruh terhadap Kualitas Informasi Laporan Keuangan (Y). Hal ini berarti bahwa kegiatan pengawasan internal telah dilakukan pada SKPD Pemerintah Kota Manado, sehingga Pemerintah Kota Manado menjamin bahwa semua pencatatan akuntansi dan keuangan pemerintah telah sesuai dengan prosedur dan peraturan yang berlaku, sehingga tujuan untuk membuat laporan keuangan yang berkualitas dapat tercapai.

2. Secara parsial, Pemahaman Sistem Akuntansi Keuangan $\left(\mathrm{X}_{2}\right)$ berpengaruh terhadap Kualitas Informasi Laporan Keuangan (Y). Hal ini berarti bahwa pegawai bagian akuntansi/keuangan pada SKPD Pemerintah Kota Manado telah memahami proses akuntansi sampai menjadi laporan keuangan sehingga tujuan untuk membuat laporan keuangan yang berkualitas dapat tercapai.

3. Secara parsial, berbeda dengan variabel pengawasan internal dan pemahaman sistem akuntansi keuangan yang memiliki pengaruh terhadap kualitas informasi laporan keuangan, untuk variabel Kapasitas Sumber Daya Manusia $\left(\mathrm{X}_{3}\right)$ memiliki pengaruh negatif terhadap Kualitas Informasi Laporan Keuangan (Y). Hal ini disebabkan karena kondisi kapasitas sumber daya manusia di bagian akuntansi/keuangan yang belum mendukung karena masih sedikit pegawai subbagian akuntansi/keuangan yang memiliki latar belakang pendidikan akuntansi dan hal ini terlihat dari data demografi responden. Sehingga dalam hal ini, Pemerintah Kota Manado perlu meningkatkan kualifikasi di bidang pendidikan, yaitu dengan menerima pegawai yang memiliki latar belakang pendidikan akuntansi agar informasi yang disajikan dalam laporan keuangan Pemerintah Kota Manado dapat memberikan keyakinan memadai.

4. Secara bersama-sama pengawasan internal, pemahaman sistem akuntansi keuangan, dan kapasitas sumber daya manusia berpengaruh dan searah/positif terhadap kualitas 
informasi laporan keuangan dengan kontribusi sebesar 29,7\%. Sedangkan sisanya sebesar 70,3\% disebabkan oleh faktor-faktor lain diluar pengujian penelitian ini.

\subsection{Saran}

Dari hasil penelitian ini penulis menyarankan sebagai berikut.

1. Pemerintah Kota Manado diharapkan dapat meningkatkan kualifikasi di bidang pendidikan, yaitu dengan menerima pegawai yang memiliki latar belakang pendidikan akuntansi. Karena dilihat dari data responden, membuktikan bahwa masih banyaknya aparatur yang bekerja di bagian akuntansi/keuangan yang berlatar belakang pendidikan non akuntansi.

2. Pemerintah Kota Manado diharapakan untuk lebih sering mengadakan pendidikan dan pelatihan terhadap software akuntansi ataupun software yang digunakan dalam bidang pekerjaannya. Hal ini merupakan salah satu bentuk dari langkah pemerintah daerah terhadap peningkatan kapasitas sumber daya manusia. Karena pemahaman yang baik terhadap software yang digunakan akan membuat aparatur lebih dapat menghasilkan laporan keuangan yang berkualitas.

3. Mengingat peran pengawasan internal sangat penting dalam hal peningkatan kualitas laporan keuangan, karena itu hendaknya peran pengawasan dapat terus ditingkatkan.

4. Diharapkan Pemerintah Kota Manado dapat meningkatkan kinerja dengan melakukan evaluasi kerja serta dapat memberikan fasilitas yang mendukung bagi kelancaran aktivitas pada SKPD Pemerintah Kota manado.

5. Untuk penelitian selanjutnya, supaya dapat mempertimbangkan atau menambahkan variabel-variabel lain yang diduga berpengaruh terhadap kualitas informasi laporan keuangan.

\section{DAFTAR PUSTAKA}

http://beritamanado.com/bpk-audit-keuangan-pemkot-manado/

Mahmudi, 2010. Analisis laporan keuangan pemerintah daerah, edisi kedua. Yogyakarta: UPP STIM YKPN.

Novi Andiani, 2012. Pengaruh Sistem Pengelolaan Keuangan Daerah Dan Implementasi Sistem Akuntansi Keuangan Daerah Terhadap Fungsi Pengawasan Keuangan Daerah (Studi Pada Dinas Pendapatan Pengelolaan Keuangan Dan Aset Daerah (Dppkad) Di Kabupaten Boyolali)

Peraturan Pemerintah Nomor 24 Tahun 2005 tentang Standar Akuntansi Pemerintahan.

Safrida, 2010. Pengaruh Pemahaman Akuntansi, Pemanfaatan Sistem Informasi Akuntansi Keuangan Daerah Dan Peran Internal Audit Terhadap Kualitas Laporan Keuangan Pemerintah Daerah (Studi Pada Pemerintah Kota Banda Aceh). Jurnal Akuntansi Vol. 3. No. 2.

Sekaran, U. 2006. Metodologi Penelitian untuk Bisnis. Jakarta: Penerbit Salemba Empat.

Susilo Prapto, 2008. Pengaruh Pemanfaatan Teknologi Informasi, Dan Pengendalian Intern Akuntansi Terhadap Pelaporan Keuangan Pemerintah Daerah. 
Winidyaningrum dan Rahmawati, 2010. Pengaruh Sumber Daya Manusia Dan Informasi Teknologi Pemanfaatan Kehandalan Dan Ketepatan Waktu Pelaporan Keuangan Pemerintah Daerah Dengan Variabel Intervening Pengendalian Internal Akuntansi.

www.infosulut.com/manado_pemerintahan_49.html

Zuliarti, 2012. Pengaruh Kapasitas Sumber Daya Manusia, Pemanfaatan Teknologi Informasi, dan Pengendalian Intern Akuntansi Terhadap Nilai Informasi Pelaporan Keuangan Pemerintah Daerah : Studi Pada Pemerintah Kabupaten Kudus. Skripsi 